RESEARCH ARTICLE

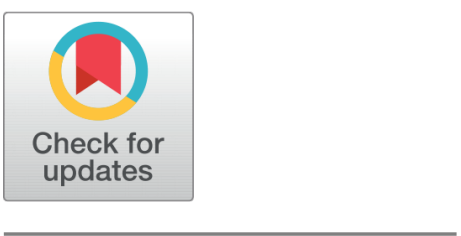

open ACCESS

Received: 22.01.2020

Accepted: 12.05 .2020

Published: 10.06 .2020

Citation: Kumar KRP. (2020). MAJOR AGRICULTURAL CROPS IN TUMKUR DISTRICT- AN OVERVIEW. Geo-Eye. 9(1): 38-42. https://doi.org/ 10.53989/bu.ge.v9i1.8

Funding: None

\section{Competing Interests: None}

Copyright: (c) 2020 Kumar. This is an open access article distributed under the terms of the Creative Commons Attribution License, which permits unrestricted use, distribution, and reproduction in any medium, provided the original author and source are credited.

Published By Bangalore University, Bengaluru, Karnataka

ISSN

Print: $2347-4246$

Electronic: XXXX-XXXX

\title{
MAJOR AGRICULTURAL CROPS IN TUMKUR DISTRICT- AN OVERVIEW
}

\author{
K R Prasanna Kumar ${ }^{1}$ \\ 1 Assistant Professor, Department of Geography, Government First Grade College, Vijayanagara, \\ Banagalore, Karanataka, India
}

\section{Introduction}

Indian economy has come of age. The impact of globalization has been relatively good so far-both in relation to our previous growth performance and that of other countries. The impact of globalization, since 1990's along with other spheres of human economy, agricultural land uses too have seen changes in Karnataka. Particularly areas adjacent to metropolitan city like Bangalore have undergone perceivable changes. The process of land use change is still on due to rise in the cost of agricultural inputs and non availability of farm labourers. Added to these two major factors, vicinity of growing urban markets for vegetables, fruits, flowers and the agricultural products have tremendous influence on agriculture.

The outset macro statistical figures under different crops show marginal changes, Micro-analysis of rural land use reveals the inherent changes of agricultural land uses due to globalization and urban induced marketing garden crops. Other distributing factors is many areas of Karnataka is some of them have already declared as dark areas in terms of availability of underground water by Central Ground Water Board. With non-availability of electricity for agricultural operations is adding further high cost to agricultural inputs. Varying and undependable monsoons i.e., drought prone conditions and increasing poverty among marginal and small farmers have pushed young generation out of villages seeking some job in city like Bangalore. This enhanced has nonavailability of farm labourers and often increasing some perennial tree crops like Mango, Tamarind, coconut gardens etc. At the cost of essential cereal crops. Farming community which was once self sufficient in regional specific cereals like Ragi and Rice are facing shortage of them with associated fodder.

\section{Study Area}

Tumkur district in southeast part of Karnataka state extends from $12^{0}-45^{\prime}$ North to $14^{0}-20^{\prime}$ north and $76^{\circ}-20^{\prime}$ to $77^{0}-31^{\prime}$ East. It has a geographical area of 10,788 $\mathrm{km}^{2}$ with a total population of $2,678,980$ (2011). Figure-1 and Table- 1 show the broad details of ten taluks of this district. Being a part of Deccan peninsular of South Karnataka it has predominately crystalline rocks like Genesis and granites and resultant red soils. The whole district forms a part of rain shadow region of peninsular India and some its eastern taluks are closer to drought prone region of central southeastern India. District receives around $660 \mathrm{~mm}$ of annual average rainfall which is again is erratic forcing the whole agriculture to depend on rainfed ground water and tanks (see Table-1). Its dry land agriculture due to no major river and irrigation projects and closerness to Bangalore city $55-160 \mathrm{~km}$ has created a sort of 'push' conditions interms of human rural urban migration. 
District has three national highways (NH48, NH206 and NH4) with a railway line (Bangalore- Miraj broad-gauge line) relatively better all weather roads. District has more or less agro-based industries than other form of industries. It has made a mark in coconut production and its industries particularly in Tiptur and other western taluks.

\section{Methodology}

Present study is totally based on the secondary sources of data. Data related to agricultural areas of different crops is obtained from Bureau of Economics and Statistics, Government of Karnataka, Bangalore. Also data on then and other aspects have been gathered from the District at a Glance of Tumkur District, Directorate of Statistics. Data has been analyzed for 19995-96, 2005-06 and 2015-16. Suitable percentages, trends in the form of growth rates and resultant tables, and figures have been computed. Correlation has been worked out between cropped area for different years and suitable inferences have been drawn.

\section{Major Agricultural Crops Cultivated in Tumkur District}

\section{Cereals}

As the district is basically a dry land predominant without an assured irrigation, the crops under this group in their order of area of cultivation are Ragi, Paddy (Rice), Minor millets (locally they are known as Navane, Korale, Save and the like. While ragi is cultivated in almost all the taluks as a Kariff crop, some amount of this crop is also grown with well and tank irrigation. Paddy or Rice is purely an irrigated crop depended on well irrigation or tank irrigation. Off late (since 1980's) extention of canal irrigation has marginally increased its area in western taluks of the district. In almost all the taluks, the cultivation of minor millets has considerably declined. This is on one hand is due to change in people's attitude towards consumption of them and on the other, the cultivation of tree crops in such marginal lands like Tamarind, Mangoes etc. in recent years. In a semiarid rain dependent cultivable lands once supported these minor millets under sustainably evolved form of agriculture. But people at present do not have the concept of sustainable concept to agriculture compared to our elders. It is a loss to agricultural bio-diversity and also to some extent food security.

A glance at Table-2 shows a distributing scenario of declining cereals growing area in the district. It has declined from $42.4 \%$ in $1995-96$ to $36.9 \%$ and further to $35.2 \%$ of total cropped area in the district. Infact, it is a loss and threatens the food security of the district. People in yester years used to be self sufficient in these basic cereal like Ragi and Rice but now they have switched over to commercial non cereals crops like groundnut or coconut, mulberry, flowers and fruits. This has made them to buy food grains and worst of it is also to buy fodder too. There is a decline in draft animals and there is an increase in use of inanimate power due to globalization (tractors, Harvesters too). Decline in bio-manure which has made farmers to use chemical manures, which too have become costly over the years has caused damage to the soils. Declining cereals in a way is adding unsustanability of agriculture in the district with other consequences which need some more space to explain.

\subsection{Pulses}

These are leguminous intertiled crops like Tur, Moong, Horsegram and the like. As the study area has predominantly rain depended cultivation along with minor millets, some of these crops too have further declined. Farmers prefer to grow exclusive by groundnut crops without much intertiling of pulses. Rise in horticultural crops area has taken the toll of these protein rich crop, exposing people to malnutrition. In earlier years most of the farmers used to compulsorily grow some amount of all the pulses but at present they depend out side sources playing very high price for them. Definitely not only it has added to vulnerability of farming community towards food security but also to malnutrition. Table- 2 shows pulses growing area in the cropped area of respective years has declined from $17 \%$ in $1995-96$ to $11.0 \%$ in $2005-06$ to $8.1 \%$ by 2015-16.

\section{Oil Seeds}

Tumkur district has two important oil seeds cultivated where in a way only groundnut is a really predominant oil seed cultivated in most of the taluks as Kharif crops. But coconut which is included here too forms an important oil crop often in exclusive grooves and also coconut palms planted along boarder of agricultural lands. Due to extension of tube well irrigation in the recent decades their cropped area has increased substantially. In each taluk and district head quarters oil industries are a common sight in the study area. Tiptur town has carved out a rich in coconut oil production and in the dry coconut kernel (copra) trade in the state. Farmers now a day's grow groundnut not only as Kariff crop but also under well irrigation in non-Kariff season. In the study period, the cultivation of these oil seeds has seen remarkable growth from $30.9 \%$ of net sown area. in $1995-96$ to $42.8 \%$ in $2005-06$ and further to $46.3 \%$ of total cropped area in the district. In the case of growth in coconut cultivation, as there is an artificial shortage of agricultural labourers as there also is rise in rural-urban migration, people have started growing garden crops like coconut which needs limited agriculture labourers.

One conspicus aspect is in the earlier years farmers used to grow castor oil seeds and Niger seeds (Huchhayellu). Their cultivation has declined in the study region in the recent years which may be due to people's attitude towards food items and changing life style. In fact, in a semi-arid region like this 
Table 1. Taluk wise Scenario of broadGeo-Socio-Economic Features Tumkur District, 2015-16

\begin{tabular}{|c|c|c|c|c|c|c|c|c|c|c|c|c|}
\hline \multirow[t]{2}{*}{ Taluks } & \multirow{2}{*}{$\begin{array}{l}\text { Geogra- } \\
\text { phical } \\
\text { Area } \\
(000 \\
\text { hac })\end{array}$} & \multicolumn{5}{|c|}{ Literacy (\%) } & \multicolumn{2}{|c|}{$\begin{array}{l}\text { Major irrigated } \\
\text { Area (\%) }\end{array}$} & \multirow{2}{*}{$\begin{array}{l}\text { Net } \\
\text { Irri- } \\
\text { gated } \\
\text { Area } \\
\text { (In } \\
\text { hac) }\end{array}$} & \multirow[t]{2}{*}{$\%$} & \multirow{2}{*}{$\begin{array}{l}{ }^{* *} \text { I.A. } \\
\text { in } \\
\text { N.S.A. }\end{array}$} & \multirow[t]{2}{*}{$\begin{array}{l}{ }^{* * *} \text { R.F. } \\
(2015)\end{array}$} \\
\hline & & Male & Female & Averag & $\begin{array}{l}\text { Net } \\
\text { Sown } \\
\text { Area } \\
(\text { in hac)* }\end{array}$ & $\%$ & Wells & Tanks & & & & \\
\hline $\begin{array}{l}\text { C.N. } \\
\text { Halli }\end{array}$ & $\begin{array}{l}113.0 \\
(10.6)\end{array}$ & 79.5 & 60.8 & 70.2 & $\begin{array}{l}57865 \\
(9.3)\end{array}$ & 51.2 & $\begin{array}{l}9913 \\
(9.7)\end{array}$ & $\begin{array}{l}28 \\
(0.3)\end{array}$ & 9941 & 6.3 & 17.2 & 496.2 \\
\hline Gubbi & $\begin{array}{l}122.1 \\
(11.4)\end{array}$ & 76.7 & 58.2 & 67.5 & $\begin{array}{l}73039 \\
(11.8)\end{array}$ & 59.8 & $\begin{array}{l}25806 \\
(96.0)\end{array}$ & $\begin{array}{l}1076 \\
(4.0)\end{array}$ & 26882 & 17.1 & 36.8 & 551.3 \\
\hline $\begin{array}{l}\text { Korat- } \\
\text { agere }\end{array}$ & $\begin{array}{l}70.9 \\
(6.6)\end{array}$ & 73.3 & 51.8 & 62.7 & $\begin{array}{l}37592 \\
(6.1)\end{array}$ & 53.0 & $\begin{array}{l}7080 \\
(98.3)\end{array}$ & $\begin{array}{l}122 \\
(1.7)\end{array}$ & 7202 & 4.6 & 19.1 & 753.4 \\
\hline Kunigal & $\begin{array}{l}99.1 \\
(9.3)\end{array}$ & 72.0 & 51.0 & 61.3 & $\begin{array}{l}57145 \\
(9.2)\end{array}$ & 58.0 & $\begin{array}{l}5288 \\
(30.0)\end{array}$ & $\begin{array}{l}7730 \\
(43.8)\end{array}$ & 17651 & 11.2 & 30.9 & 848.0 \\
\hline Madugiri & $\begin{array}{l}112.1 \\
(10.5)\end{array}$ & 72.7 & 49.4 & 61.2 & $\begin{array}{l}54727 \\
(8.8)\end{array}$ & 49.0 & $\begin{array}{l}12801 \\
(99.7)\end{array}$ & $\begin{array}{l}39 \\
(0.3)\end{array}$ & 12840 & 8.2 & 23.5 & 582.4 \\
\hline Pavagada & $\begin{array}{l}135.8 \\
(12.8)\end{array}$ & 68.6 & 44.0 & 56.5 & $\begin{array}{l}86955 \\
(14.0)\end{array}$ & 64.0 & $\begin{array}{l}11330 \\
(7.8)\end{array}$ & $\begin{array}{l}258 \\
(2.2)\end{array}$ & 11588 & 7.4 & 13.3 & 415.5 \\
\hline Sira & $\begin{array}{l}15.4 \\
(14.6)\end{array}$ & 73.1 & 51.4 & 62.4 & $\begin{array}{l}87883 \\
(14.3)\end{array}$ & 56.5 & $\begin{array}{l}17087 \\
(91.6)\end{array}$ & $\begin{array}{l}1567 \\
(8.4)\end{array}$ & 18654 & 12.0 & 21.2 & 591.2 \\
\hline Tiptur & $\begin{array}{l}76.5 \\
(7.3)\end{array}$ & 83.7 & 66.2 & 75.0 & $\begin{array}{l}50258 \\
(8.1)\end{array}$ & 66.0 & $\begin{array}{l}9381 \\
(65.3)\end{array}$ & $\begin{array}{l}4981 \\
(34.7)\end{array}$ & 14362 & 9.2 & 28.6 & 647.4 \\
\hline Tumkur & $\begin{array}{l}103.8 \\
(9.7)\end{array}$ & 82.3 & 67.1 & 75.0 & $\begin{array}{l}60702 \\
(9.8)\end{array}$ & 58.5 & $\begin{array}{l}22051 \\
(97.9)\end{array}$ & $\begin{array}{l}464 \\
(2.1)\end{array}$ & 22515 & 14.3 & 37.1 & 796.4 \\
\hline Turuveker & 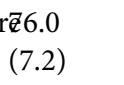 & 81.7 & 61.1 & 71.0 & $\begin{array}{l}53488 \\
(8.6)\end{array}$ & 70.4 & $\begin{array}{l}7855 \\
(51.5)\end{array}$ & $\begin{array}{l}7387 \\
(48.5)\end{array}$ & 15242 & 9.7 & 28.5 & 671.7 \\
\hline $\begin{array}{l}\text { District } \\
\text { Total }\end{array}$ & 1064.7 & 76.8 & 56.9 & 67.0 & 619654 & 58.2 & $\begin{array}{l}128592 \\
(82.0)\end{array}$ & $\begin{array}{l}23652 \\
(15.1)\end{array}$ & 156877 & 14.7 & 25.3 & 635.4 \\
\hline
\end{tabular}

${ }^{\star}$ In the Geographical Areaof Taluk. ${ }^{*}$ Percentage of Irrigated area in Net Sown Area. ${ }^{* *}$ Average AnnualRainfall in mm.

Source: Tumkur District at a Glance, 2017 -18, Government of Karnataka

Table 2. Major AgriculturalCrops in Tumkur District, 1995-96, 2005-06 and 2015-16

\begin{tabular}{|c|c|c|c|c|c|c|c|c|c|c|}
\hline & \multirow{2}{*}{ Crops } & \multicolumn{3}{|l|}{$1995-96$} & \multicolumn{3}{|l|}{ 2005-06 } & \multicolumn{3}{|l|}{$2015-16$} \\
\hline & & $\begin{array}{l}\text { Area } \\
\text { (in hec.) }\end{array}$ & $\%$ & GR & $\begin{array}{l}\text { Area } \\
\text { (in hec.) }\end{array}$ & $\%$ & GR & $\begin{array}{l}\text { Area } \\
\text { (in hec.) }\end{array}$ & $\%$ & GR \\
\hline A. & Cereals & $2,18,609$ & 42.4 & - & $2,20,037$ & 36.9 & +0.06 & $2,31,358$ & 35.2 & +0.51 \\
\hline B. & Pulses & 91,407 & 17.7 & - & 65,297 & 11.0 & -2.85 & 53,158 & 8.1 & -1.86 \\
\hline C. & Oil Seeds & $1,58,997$ & 30.9 & - & $2,54,762$ & 42.8 & +6.02 & $3,04,524$ & 46.3 & +1.95 \\
\hline D. & Spices & 4,286 & 0.8 & - & 5,194 & 0.9 & +2.12 & 5,497 & 0.8 & +0.60 \\
\hline \multirow[t]{3}{*}{ E. } & Other Commercial Crops & 41,595 & 8.1 & - & 45,137 & 7.6 & +0.85 & 60,328 & 9.2 & +3.36 \\
\hline & Total Cropped Area & $5,14,896$ & 100.0 & - & $5,95,499$ & 100.0 & +1.60 & $6,57,865$ & 100.0 & +1.05 \\
\hline & Net Sown Area & $5,04,287$ & - & - & $5,73,244$ & - & +1.40 & $6,19,654$ & - & +0.81 \\
\hline
\end{tabular}

Source : Bureau of Economic and Statistics, Government ofKarnataka, Bangalore 
these crops are highly desirable and their consumption too is healthy but unfortunately the ubiquitous trading of some of fashionable imported items have caused their decline and loss of bio-diversity in food /oil crops

\section{Spices}

Basically the study region is not a major spice crops area, but this included the cultivation of mostly Redpepper (chillies), small quantities of coriander, fenugreek and the like. A few decades back most of the families in the Karieff season used to grow them on a sustainable basis. In a piece of land often less than even $\frac{1}{2}$ acre they used to grow chillies with many inter tilled vegetables (Bringal, Ridge guard, Lady finger and may others). In the edge of the plot they used plant special variety of caster and tur with pumpkin like guards. By the end of each karieff season most of the farmers used to have enough home grown chillies and vegetables. By autumn /Rabi season they used to grow coriander, fenugreeks and Block gram etc., which has vanished almost of the villages in the study area. This is mainly due to people's greed to grow in a larger area either maize or groundnut as commercial crops under well irrigation. No doubt they are getting some income but they are forced to loose nutrient originated home grown vegetables and other species. There is a greater loss of agricultural biodiversity due to decline of their cultivation.

But the cultivation of Green chillies and raw coriander for growing urban markets have shown the rise in spice growing area. It has increased over the years to more or less than $1 \%$ of total cropped area in the region during the study period.

\section{Other commercial crops}

Mostly consists of tree crops like Mango, Tamarind etc. in the study region. In the recent years as it has been explained earlier under coconut crop, there is a shortage of farm labourers, which is truly a in populous country like ours. Urban literate farmers more and more nuclear families, migration of youths to cities like Bangalore have forced the farmer to grow more and coconut, Mango and Tamarind by less labour. As they are annuals and commercial crops their cultivation suites their urban mode of living too. The worry some factor is that, some of the valuable, cereals /food crops growing areas are being increasingly brought under their annuals. Off late these crops too are facing glut even in globalizing world. They are forcing losses and they have been frequently ravaged by hailstorms, unusual occasions, heavy rains with gales and in some years famines too. In fact 2010 Mango crop season is a best example exported crop has dwindled to mere $20-30 \%$ !
There is an overall remarkable rise in their absolute cultivated area in the total cropped area. They had $8.1 \%$ in $1995-96$ if slightly declined to $7.6 \% 2005-06$, and due to aforesaid factors by $2015-16$ there is substantial rise to $9.2 \%$ of total cropped area.

\section{Conclusion with strategies}

1. There is a distributing trend of declining cereals like Ragi, Rice and minor millets under the impact of rise in the cultivation of commercial crops like mulberry, urban market oriented and fruits (mango). People must raise draft animals while growing some of them which provides biomenure and enhance fertility of the soil. People once again get food grains and fodder, which is not available at present like earlier, farmers depend PDS and market sources for essentials!

2. Cultivation of pulses needs attention and farmers must reintroduce the former type of their inter tillage. This provides protein food security along with even fodder security, which is fast eroding in the study region.

3. Though at the outset, cropped area under oil seeds has shown substantial rise in the cropped area but there is a loss of Caster and Niger seeds growing area which are also important must be grown by farming community. There is a need to introduce their cultivation for healthy food habits and protection of agricultural plant biodiversity.

4. Due to early urban market there is some rise in the cultivation of species like chilies and coriander. But in the earlier days most of the farmers used to grow a variety of vegetables, oil seeds and species in a small piece of land under sustainable way. This need to be reintroduced as it has nutritional value but at present people one depending on weekly markets round the years. The decline of sustainable spices on one hand has eroded agricultural sustainability, and biodiversity and overall physical health of people.

5. Due to some recent socio-economic factors other commercial cropped area is in rise at the cost of food crops. At present rural youths are migrating leaving agriculture there by the artificial shortage of agricultural labourers. This trend must be reversed to make not only better living but also overall sustainable growth of Indian agriculture. It requires not only 'PURA' like rural development, but also rural youth must follow sustainable diary cum agriculture with value addition to their agricultural products at rural level. 


\section{References}

1) Majid H. Systematic Agricultural Geography. Jaipur. Rawat Publication. 2002.

2) Agricultural Statistics at a Glance. 2008.

3) Swaminathan MS. Agrarian Prosperity in our Quest for Quality Produce. The Hindu. 2002;p. 9-14.
4) www.agricultureinindia-wikipedia. .

5) Pingali P. Food Security Challenge Played by Complex Issues", The Hindu Survey of Indian Agriculture. The Hindu. 2002.

6) Tumkur District at a Glance, 1996-97, 2006-07,2016-17 Office of the District Statistics, Tumkur.

7) www.foodsecurity-wikipedia. . 